\title{
Strategic options for the newspaper publishing companies
}

Citation for published version (APA):

van Kranenburg, H. L. (2004). Strategic options for the newspaper publishing companies. METEOR, Maastricht University School of Business and Economics. METEOR Research Memorandum No. 003 https://doi.org/10.26481/umamet.2004003

Document status and date:

Published: 01/01/2004

DOI:

10.26481/umamet.2004003

Document Version:

Publisher's PDF, also known as Version of record

\section{Please check the document version of this publication:}

- A submitted manuscript is the version of the article upon submission and before peer-review. There can be important differences between the submitted version and the official published version of record.

People interested in the research are advised to contact the author for the final version of the publication, or visit the DOI to the publisher's website.

- The final author version and the galley proof are versions of the publication after peer review.

- The final published version features the final layout of the paper including the volume, issue and page numbers.

Link to publication

\footnotetext{
General rights rights.

- You may freely distribute the URL identifying the publication in the public portal. please follow below link for the End User Agreement:

www.umlib.nl/taverne-license

Take down policy

If you believe that this document breaches copyright please contact us at:

repository@maastrichtuniversity.nl

providing details and we will investigate your claim.
}

Copyright and moral rights for the publications made accessible in the public portal are retained by the authors and/or other copyright owners and it is a condition of accessing publications that users recognise and abide by the legal requirements associated with these

- Users may download and print one copy of any publication from the public portal for the purpose of private study or research.

- You may not further distribute the material or use it for any profit-making activity or commercial gain

If the publication is distributed under the terms of Article $25 \mathrm{fa}$ of the Dutch Copyright Act, indicated by the "Taverne" license above, 


\title{
STRATEGIC OPTIONS FOR THE NEWSPAPER PUBLISHING COMPANIES
}

by

\section{H.L. (Hans) van Kranenburg*}

\author{
University of Maastricht \\ Faculty of Economics and Business Administration \\ Department of Organization and Strategy \\ P.O. Box 616 \\ 6200 MD Maastricht \\ The Netherlands \\ Tel: (31) 43-3883823 \\ Fax: (31) 43-3884893 \\ e-mail: h.vankranenburg@os.unimaas.nl
}

February 2004

*H.L. (Hans) is an associate professor of Industrial Organization and Strategy at University of Maastricht, the Netherlands. His research interests concern industry dynamics, anti-trust issues, multimedia, information and communications industries and strategic behavior of firms. His work is published in e.g. Journal of Law and Economics, International Journal of Industrial Organization, Review of Industrial Organization, Managerial and Decision economics, International Studies of Management and Organization, Journal of Media Economics. 


\title{
STRATEGIC OPTIONS FOR THE NEWSPAPER PUBLISHING COMPANIES
}

\begin{abstract}
The traditional publishing markets are undergoing a fundamental transformation. These developments pose threats to the traditional newspaper publishing companies, but also create new opportunities for these companies to engage in profitable new ventures and businesses. The companies have to find their way in the turbulence landscape. This study contributes to the existing analysis on the publishing strategy topic by putting the forces active in the market into perspective and by narrowing the problem down to such an extent that current and future changes in the publishing industry can be linked to possible strategic choices. A newspaper publishing company's competitive advantage for copying with the rapid changes in the landscape is not in its current distinctive competencies, but in those that it can grow tomorrow.
\end{abstract}




\section{Introduction}

The traditional publishing landscape has changed decidedly during the past decade.

Technological and demographic developments, deregulation and the convergence of different information and communications markets have left an important mark on the configuration of the traditional publishing industry (Wirtz, 2001; Picard, 2003). Not only have these developments pose threats to the industry, but also create new opportunities for publishing companies to engage in profitable new ventures and businesses. While the performance and survival opportunities of traditional publishing companies, in particular the newspaper publishing companies, have been poor over the last decade it is expected that these companies will encounter serious problems to create strategies that will be able to benefit from the forces currently changing the traditional publishing landscape. Even if traditional newspaper publishing companies - on average- have been profitable in the last decades, their real competitive strength has been questioned. It is possible that the publishing company shows sign of above-average performance but do so without having a sustainable competitive advantage. It is likely that they have adopted the harvesting strategy. Some studies have pointed at the spiral of decline in the traditional publishing industry, in particular newspapers, due to destabilizing force of such factors as new entrants from outside the industry, innovations from existing information and communications companies and changes in customer behaviour. These developments are shown in many countries, for instance, in Argentina, Ireland, the Netherlands, North American and Nordic countries (Carroll, 1995; Sollinge, 1999; Kranenburg, Palm and Pfann, 2002). Newspaper publishing companies in these countries operate in more or less similar circumstances and under similar conditions.

The management team of these companies has had considerable difficulty in addressing the challenges raised by the rapid pace of current change in the traditional publishing industry. 
Declining profits because of increased competition and environment uncertainty have led to doubts about the newspaper publishing companies strategies' viability. Not only management, but also empirical evidence has failed to find conclusive answers on matters like scale and scope economies, alliances and consolidation benefits.

Newspaper publishing companies will have to find their way in the information and communications landscape. This information and communications landscape is a playing field larger than the traditional publishing environment. In order to survive and prosper in the today's changing industry structure and competitive situation, newspapers publishing companies clearly require a viable competitive strategy. They have to make adequate adaptations to these dynamic changes and respond quickly to create or to sustain their competitive advantage (Picard, 2003). This article contributes to the existing analysis on the publishing strategy topic by putting the forces active in the market into perspective and by narrowing the problem down to such an extent that current and future changes in the publishing industry can be linked to possible strategic opportunities.

\section{Cost Leadership Strategy}

What makes some newspaper publishing companies consistently more profitable than others within the same industry? Strategy issues for the newspaper publishing companies, which are closely related to the question, are why newspapers publishing companies differ, how they behave, how they choose their strategies and how they are managed. Of course, there exists a multitude of strengths and weaknesses that firms can have compared to their competitors. However, a firm can only posse two basic types of competitive advantage: cost leadership or differentiation (Porter, 1985). Other strengths and weaknesses are not less important but together determine either a cost leadership- or differentiation strategy. 
Newspaper publishing companies pursuing a cost leadership strategy aim to become the low cost producer of information and communications products in the industry. These firms usually have a broad scope and serve many market segments. They may even operate in related industries, such as broadcast market (Ferguson, 1983) because this breadth of operations is often crucial in achieving cost-advantages. The way these cost advantages can be achieved depends on the structure of the industry. The cost structure of the publishing industry is characterized by a relative high ratio of fixed costs. The competitive cost advantages of publishing companies arises from the differences in capacity costs and high first-copy costs, like the collection and organization of editorial and advertising copy and preparation of the printing mechanism. These costs are ineluctable to produce even one product, while the marginal production costs of the subsequent products are very low (Picard and Brody, 1997). Ownership of two or more newspapers or ownership of broadcast stations and newspapers provides publishing companies opportunities for economies of size in news gathering, in securing advertising, in financing, and in management by lowering average and marginal costs. The costs advantages are greater for chain ownership, for high aggregate circulation, and for homogeneous products (Rosse, 1967; Norton and Norton, 1986).

Economies of scale are related to economies of scope, and these two terms are often used interchangeable. Economies of scope occur when a multi-product firm can produce given quantities of products at a lower total cost than the total cost of producing these quantities in separate firms. In other words, newspapers publishing companies have to ally parts of their value chain to benefit from savings across business activities. For instance, publishing companies can reduce the total administration costs when they have only one subscription network, instead of separate networks for their products. Another possibility is to outsource the subscription routines to independent companies, what already happens for magazines in Sweden (Hafstrand, 2002). 
Thus, an interesting option would be that the companies mainly concentrate on their core competence, collecting, processing and analyzing news, entertainment and information for their customers, while it can be argued that the other activities does not capture the core value creation logic of a newspaper publisher.

An important feature of a cost leader is that it will exploit all sources of cost advantage. In order to achieve a superior performance a cost leader must ensure that its products offering is of similar value to customers than that of its competitors. This is needed in order to translate the cost advantages obtained from using economies of scale and scope directly into higher profits. Newspaper publishing companies can achieve cost advantages with economies of scale and scope in the following areas:

- Information technology: This source may have great potential for publishing companies to achieve economies of scale and scope. The recent information technology developments facilitate an increase in efficient and effective utilization of information over ranges of products, services and customers. Information may allow for scope economies and facilitate competitive advantage to publishing companies that can offer a range of products and services to their customers. The possibility for reusability of information across customers has increased. Furthermore, the information technology developments may help facilitate differentiation of products and services (Chyi and Sylvie, 1998). New technologies such as the internet and online subscription services make it possible to combine old and new media into one product with an additional element that was missing in the earlier markets: interactivity. The integration of activities allows a greater personalisation of relationships and interactivity between customers and publisher. The company can offer bundle of services and products into a complete service package for the customer (Wirtz, 2001). Newspaper publishers could offer services such as interactive 
forum, searchable news archives, online transactions, up-to-the minute information, and audio/video presentations. It is in the increased integration of activities and new technologies that lay the potential competitive advantage of publishing companies. Therefore, publishing interacts with many different fields within the information and communications industries and technologies. Because of this diversification publishing companies may have to redefine their 'core business'. However to use these technologies in a competitive way, substantial investments in capital and expertise is required.

- Distribution network: An important cost driver for the publishing industry, in particular the circulation industry, is distribution. For instance, distribution costs contribute about 20 percent to the total costs of a newspaper publishing company. See table 1.

------insert Table 1 about here-----

These companies can reduce their costs when they utilize more intensively their transportation network within a geographical territory, or when they generate the same volume of business in geographically smaller area as in a geographically larger area. These cost savings refer to economies of density. It is actually economies of scale along a given route that is reductions in average cost as volume on the route increase (Besanko, Dranove and Shankley, 1996). Of course, the recent technological developments may facilitate scale economies offering gains in running a greater sizable distribution network. The information technology enables companies to manage their network more efficient and faster. Hence, publishing companies can reduce the total cost of distribution when they have only one common distribution network, instead of separate networks for their products or they can outsource their distribution activities to independent companies. The 
distribution function of magazines in Sweden is already carried out by independent companies, although the largest distribution company, Tidsam, is owned and controlled by the larger magazine companies (Hafstrand, 2002)

- Production: Most of the existing studies on scale and scope economies focused on the potential production cost savings for traditional publishing companies. These studies showed the existence of economies of scale due to spreading product-specific fixed costs in circulation industries (Rosse 1967; Kranenburg et al., 2002). The production process of publishing products often involves high fixed costs. The product-specific fixed costs include the relative high expenses to set up a production process, for example, the time and expense required to set up a newspaper before printing. Newspaper publishing firms that produce the dominant design product in the market develop a competitive advantage. Hence, economies of scale in producing a (circulation) product are incorporated as a result of the possibilities of mass production of the product. Sufficiently strong scale economies can give large publishing companies enough cost advantages to force smaller and less efficient companies out of the market when the possibility of mass production increases or when the industry specific conditions become less favourable.

- Marketing and reputation: The next source of potential scale and scope economies is linked to marketing and reputation. It is generally understood that marketing may enlarge the readership of a newspaper (Picard, Winter, Mccombs and Lacy, 1988). Because marketing expenses involve substantial fixed costs, this implies the existence of economies of scale. Also, scope benefits may be present in the joint marketing of products to customers (Scherer and Ross, 1990). Another purpose of marketing is to create a brand image and loyalty of customers. Image and loyalty are related to the notion of 'reputation'. A company can build up a reputation with a consistent policy, marketing and 
highly qualified products and services. Reputation plays an important role in the publishing industry. Newspaper publishing companies offer products that crucially depend on their reputation and reliability. In general, customers relate closely the reputation and reliability of the publishing company to the quality of its products and services. Furthermore, the companies operate in industries that are characterized by the existence of a demand interdependence process. Circulation products are sold in two markets: the reader market and the advertising market. A change of a publisher's reputation in one market will affect the sells in both markets (Albarran, 1996). Increasing scale and scope allow publishers to capitalize more on their reputation. That is, a wider scope or scale may help a publishing company 'to put its asset 'reputation' at work'. For instance, an interesting aspect is that large companies and or companies with a very good reputation may have bargaining power to negotiate lower prices for their production inputs. Publishers can also use their reputation to diversify into number of unrelated and related businesses that are centered around their core business (Kranenburg, Cloodt and Hagedoorn, 2001).

- Innovations: Innovation in the publishing industry is an important source of scale and scope economies. Schumpeter $(1934,1942)$ argued that innovations give companies temporally monopolies because they have no competitors on the same playing field until a company duplicates or betters the innovations or products. These temporally innovations are essential for the publishing companies because they can protect or increase the market share. Or even better they generate funds to strength their competitive position. For instance, the appearance of free newspapers has had a significant impact on the traditional newspaper market (Picard, 2001). The concept of free newspapers is based on only advertising income and free distribution in and around metropolitan public transportation 
systems. After the successful introduction of Metro in Stockholm incumbents and new entrants across the globe have begun launching also free newspapers. In general, the first movers in the geographically delimited markets had sooner or later to compete with other free newspapers. The R\&D costs occurred by the first movers is likely to be higher than for the followers, because followers generally have to put less effort on the legitimacy of the innovation in the market. The existence of economies of scope and scale enables the first movers to spread the fixed costs of research and development over more customers. Innovations could be marketed to a larger consumer base and/or introduced in a wider set of activities. For innovations in the publishing industry scale and scope might be particularly important given the rapid speed of innovations and imitation by competitors. Only for a short period of time does a true competitive advantage exist. For instance, the introduction of the internet site by newspapers created a competitive advantage for those newspapers that introduced these innovations. In the Netherlands, the national daily newspaper NRC-Handelsblad was the first to enter the electronic newspaper market in 1995, shortly followed by its competitors, in particular the large newspapers. The larger newspapers had a higher opportunity to enter the electronic market than the smaller papers because of the needed investments. Increasing scale and scope allow publishing companies to recoup the fixed costs in this short period of time. Furthermore, large-scale companies can readily use internal capital reserves or raise funds on financial markets. Thus large publishing companies can start innovate activities almost immediately.

\section{Differentiation Strategy}

Publishing companies pursuing a differentiation strategy, seek to be unique in its industry along some dimensions that are widely valued by customers (Porter, 1985). They may seek one or 
maybe a few attributes that a large amount of customers find important and positions themselves uniquely to meet those needs. In other words, the differentiation strategy must add value in terms of greater customers satisfaction, lower cost, and unique features. When a newspaper publishing company offering a product and/or service or product and service group perceived by the customers as unique, the company is rewarded by a price premium. Of course, in the order to achieve superior performance a publishing company must ensure that the price premium earned exceeds the extra costs incurred for being unique. Differentiation is based upon firm-specific skills and creates a durable asset that is difficult to imitate or creates commitment of consumers. Therefore, it can create a sustainable competitive advantage for companies. For instance, it is difficult for many newspaper publishers around the world to imitate the image and reputation of specialized newspapers like the Financial Times and Wall Street Journal. These newspapers are highly specialized in economic and financial information. Newspaper publishers also have to realize the importance of product differentiation in the on-line market. These products have to distinguish themselves from traditional media and also between other online products. The first group of differentiation refers to the development of internet-specific features such as a two-way communication, hypertext, and multimedia context that are not available in the traditional products. The differentiation between online products mainly has to focus on the information provided (Chyi and Sylvie, 1998, 2000; Hujanen, 2001)

The differentiating characteristics/attributes of publishing products can be divided into tangible and intangible features. The tangible features are observable differences that make the products or services better, cheaper or faster. For the publishing company this may include size, design features, material used, new technology that the product can now made of, consistency, speed of delivery, and accessories. The other group of features say something about the customer. The created "aura" of the product is important. The intangible aura of publishing products is one 
of image, lifestyle, quality and political, occupational, geographical or ethnical orientation. In short, the ability of a publishing company to implement a differentiation strategy crucially depends on the diversity of characteristics of consumers.

The impact that differentiation has on demand depends also on the competitive nature of the publishing product market environment. Two closely related concepts are important in the differentiation effort of publishing companies. These concepts are the stage of the product market evolution and the product life cycle (Hofer, 1975; Hill, 1988). The four stages of the two cycles are introduction, growth, maturity and decline phases (Vernon 1966; Gort and Klepper, 1982). These concepts develop simultaneously, however, when a product or product group may have its own life cycle within a broadly defined market. To formulate the strategy for a publishing company and also to determine its success, it is important to make a distinction between the structure of the market and the growth stage of the industry. Efforts to implement a differentiation strategy of publishing companies may be important in less fragmented mature markets, in particular established oligopolistic markets. In general, firms operating in these markets have achieved a minimum cost position and they can gain a sustainable competitive advantage only through some form of differentiation. As long as the products, services or product groups contain attributes to offer opportunities for differentiation than the differentiation strategy may be necessary to maintain current levels of demand. Hence, in these markets differentiation will not increase market share enough to enable the companies to realize substantial cost advantages, but to maintain its scale economies and safeguards its market share. However, the differentiation strategy can be successfully used to increase market share in emerging and rapid growth markets that are characterized by a low fragmentation. Under rapid growth conditions, entry of potential companies and differentiation to increase output will not necessarily reduce competitors' sales and decrease their profits. In these markets the incumbent firms will have less 
incentive to engage in aggressive response behaviour. Apart from the ability of the company to increase output, it can also realize scope and scale economies through differentiation. As long as the increase in costs due to differentiation is outweighed by reductions of costs associated with expanding output can differentiation be seen as a way of achieving a low cost-position.

Differentiation efforts of companies operating in highly fragmented markets can also increase demand and help them to maintain a cost-advantage position. In general, the companies operating in high growth markets have the greatest opportunity to implement successfully a differentiation strategy to increase demand.

For newspaper publishing companies to maintain or create a sustainable competitive advantage, it is important to identify specific industry environments within which the cost advantage and differentiation strategy are likely to succeed. Efforts of differentiation in high growth markets and fragmented markets are more likely to realize economies of scale and scope. In slow or negative growth markets, as the printed newspaper market, a publishing company's expansion must take place at the expense of its competitors' market shares. In addition, through the increase in competition, companies are becoming more price and cost conscious, and as a consequence, they focus more on producing the dominant design product or product group to enjoy economies of scale and scope. Newspaper publishing companies can implement only successfully a differentiation strategy to increase output in mature markets that are fragmented or when it is possible to distinguish themselves again. The impact that the (publishing) product market environment has on the publishing companies' ability to differentiate is given in Table 2 . This model developed by Hill (1988) is applied to the publishing industry. Publishing companies need to vertically integrate into the supply chain and or diversify into related and unrelated activities to implement successfully the differentiation and the cost advantage strategies in the near future. Product and international diversification is leading many publishing companies to 
pursue opportunities in the variety of new content providers that are developing and gaining significant public acceptance and also in the traditional businesses (Picard, 2003). It is obvious that publishing interacts with many different fields within the information and communications industries and their technologies, nowadays.

-----Insert table 2 about here--------

\section{Strategy Under Uncertainty}

The problem of publishing companies is that they do not know what combination of activities will give them a competitive advantage in the future. In general, traditional newspaper publishing companies have become too dependent on their existing environment. In their search for competitive advantages and higher profitability, it is not only necessarily important for these companies to enter new set of activities within new businesses but also exam the opportunity to enter traditional businesses that they traditionally choose to abstain from. Early entry, or better, choosing a wider set of activities would let the newspaper publishing companies discover which set of activities within the traditional and new businesses optimally fit together.

To create or maintain its competitive advantages, a publishing company obviously has two choices to deal with the new uncertain developments (Courtney, Kirkland and Viguerie, 1997).

One is to wait and see whether the market indeed offers the opportunities it thought it would. The publishing company should interpret the developments in the industry as a given fact. Hence, the publishing company will be a follower and have to rely on their flawless execution and imitation for competitive advantage. In particular, the adapter strategy makes sense for most small-sized publishing companies, because they do not have the financial resources and 
capabilities to explore the (potential) opportunities. This strategy's downside is, however, that the company may be too late to capitalize on the activity's profitability or that it has to make costly resource allocations it cannot afford anymore at that time. Therefore, the alternative option is to enter the new market early and find out whether the market does offer the expected profitability. This option permits the company to experience with a new business and to learn whether it has the capabilities and core competencies for this new business. When competition intensifies, the company has better knowledge about its own capabilities and market opportunities. The publishing company can expand in this business successfully, when it knows its capabilities are superior to those of its competitors and it should decide to exit the market when its capabilities are inferior. In the latter case, the publisher does not loose huge investments.

It is recommendable that the publishing company should use the scope expansion strategy to anticipate to future competitive environment for the new businesses. By following the scope expansion strategy a publishing company reserves the right to play in a variety of new activities. When the anticipated competition for the new activity is intensive due to for instance potential future competitors, early entry would be an optimal strategy. By making incremental investment and alliances today, the publishing company puts itself in a privileged position through acquisition of superior information by learning, development of a beneficial cost structure and creation of relationship with (potential) customers and suppliers. The strategy of publishing companies in the rapid changing environment may encompass several actions such as internal investment or to set up alliances, joint ventures, to acquire other companies and to divest activities. 


\section{Value of Major Strategic Options}

Newspaper publishing companies can internally developed activities that build on their competence in news, context and analysis. The decision to build independently on their traditional activities and looking for opportunities to create competitive advantages in a structural changing environment is a perilous route for the company. Publishers focusing only on internal development must frequently overcome technical constraints and legitimacy concerns in order to market products and services. Furthermore, the publishers often lack the financial funds, knowledge of the organizational and technical capabilities and skills that they require to create new businesses or to adapt existing businesses, in particular the small companies. However, in continue changing market conditions in the coming years, publishing companies need to begin to transform themselves into sustainable companies which rationalize current operations and adapt to changing technologies, markets, methods and competitive strategies (Picard, 2003). The absorption of at least part of the environment by means of mergers and acquisitions is one of the alternatives that publishing companies have if they attempt to reduce uncertainty, increase control over environmental changes, catch-up with new technological developments and trends or reduce their dependency on an existing environment (Hitt, Ireland and Hoskisson, 2002). A merger may help to create deep pocket so that investments in strategic options are more affordable.

Furthermore, it may lead to diversification in capabilities. Of course, divestments may also be undertaken to finance some of the strategic options in which a company intends to engage. Companies must divest activities that are not part of the core-business anymore or activities which not generate the normal and necessary returns on investment. For instance, the company VNU divested its newspaper activities to finance the acquisition of AC Nielson Corporation in 1999. VNU has successfully transformed its company from a newspaper publishing company into an international information company. 
A publishing company can choose to acquire the operating assets of another company in exchange for either cash, securities, or a combination of both. It acquires a stake in the other company. This means that the publishing company will have a certain degree of authority (or even full control) of what happens in the acquiring company. However, in some cases the publishing company may have difficulties in implementing the merger and acquisition strategy. For instance, the anti-trust authority can play a decisive role in the strategy of publishing companies. A merger or an acquisition by a publisher of another publishing company is generally not allowed when the company will obtain a too dominant market share. This is one of the reasons why alliances are an important alternative to mergers and acquisitions. This concept is underdeveloped in the context of publishing activities. This is to some extent surprising. The choice for an alliance can be a simple non-equity agreement - a cooperative alliance - to a partly equity transaction as a joint venture. The cooperative alliance is any contractual alliance between two or more industry incumbents or between companies that posses necessary complementary assets in which none of the companies have a degree of ownership, while a joint venture is a joint effort to achieve interests through the formation of a new entity by two or more business partners. Alliances provide access to a range of capabilities needed to develop focal and complementary goods, whereas the capabilities are often beyond the scope of any individual publishing company, in particular the small ones. The alliance strategy combines the benefits of an integrating (broader focused) publishing company and a stand-alone type of organization to maintain its current strategic position. In particular, it enables a publishing company to build a more-broader focused information and communications company next to running the relationship-rooted specific or regional publishing activities are prevented. In comparison to the internal development and acquisition strategy, the companies do not need deep pockets to implement the alliance strategy. In addition, the alliance strategy may enable in particular a large publishing company to act as a 
strategic player that can maneuver itself in a central position in between other companies. The company that is able to occupy a central position also has the potential to control the flows of information between these other companies. A central position in an inter-firm information and communications network provides the publishing company more insights in the dynamics of the markets that enables the company to use its visible position to further strengthen its position.

Of course, the alliance strategy does not come without cost (Garette and Dussauge, 2000). The important task for managers is to define a clearly defined portfolio of activities that would become part of the alliance, a portfolio of businesses to operate in and also the number of alliances. This is in particular important for small companies because they generally do not have the capability to manage a large number of partnerships and also many different forms of alliances. They must concentrate on just a few activities to improve on their strength in news, context, and analysis and have to be more careful in selecting their partner(s). Furthermore, existing networks may lock publishing companies into unproductive relationships, preclude partnering with other viable companies or may be unstable. Thus, a publishing company's network of relationships is a source of both opportunities and constraints. Because the landscape becomes sharply more competitive, the company's network enhances strategic importance and increases the survival opportunities of the publishing company.

\section{Conclusions}

Competitive pressure is forcing newspapers publishing companies to discover their competitive advantages, and choose an optimal configuration of services and activities. Due to rapid pace of changes in the traditional publishing industry the structure of the industry may be very different from the past. The current developments are just an interesting start. 
To survive, publishing companies are forced to reconsider their strategy and product portfolio. A publisher's ability to change its organizational structure and existing activities and businesses along the evolution of technology in the industry can be seen as a major source of failure or success. This study helps managers understand how the competitive dynamics and company strategy are related. If managers have a better perspective of how their strategies are influenced by their context, they may examine the impact of such influence on the publishing company performance and be more conscious and aware of their company own strategic behavior. It is recommended that they focus more on the opportunities of partnerships in the near future.

Finally, a publishing company's competitive advantage for copying with the rapid changes in the landscape is not in its current distinctive competencies, but in those that it can grow tomorrow. A company's organizational ability to leverage and strengthen existing competencies is important, but it must be equally adept at diversifying its competence base. The bases for a publishing company's sustainable competitive advantage are its distinctive competencies. The strategic choices pursue by individual newspaper publishing companies will be influenced by a variety of local market conditions and internal organizational and operational factors. Although the strategies will differ among companies, they must continually emphasize and improve on their strength in news, context, and analysis. This is the core competence of these companies and also their competitive advantage. 


\section{Reference}

Albarran, A. (1996). Media Economics: Understanding Markets, Industries and Concepts. Ames: Iowa State University Press.

Besanko, D., D. Dranove, and M. Shankley. (1996). Economics of Strategy. New York: John Wiley.

Carroll, G.R. (1995). 'Newspaper Publishers,' in Carroll G.R. and M.T. Hannan (ed.).

Organizations in Industry: Strategy, Structure and Selection. chapter 9. New York: Oxford University Press.

Chyi, H. I. and G. Sylvie. (1998). 'Competiting with Whom? Where? And How? A Structural Analysis of the Electronic Newspaper Market,' Journal of Media Economics, 11 (2), pp. 1-18.

Chyi, H.I. and G. Sylvie. (2000). 'Online Newspapers in the US - Perceptions of Markets, Products, Revenue and Competition,' International Journal of Media Management, 2 (2), pp. 6977.

Courtney, H., J. Kirkland and P. Viguerie. (1997). 'Strategy under Uncertainty,' Harvard Business Review, 75 (6), pp. 67-79.

Ferguson, J.M. (1983). 'Daily Newspaper Advertising Rates, Local Media Cross-Ownership, Newspaper Chains, and Media Competition,' Journal of Law and Economics, 26, pp. 625-654. 
Garette, B. and P. Dussauge. (2000). 'Alliances versus Acquisitions: Choosing the Right Option,' European Management Journal, 18 (1), pp. 63-69.

Gort, M. and S. Klepper. (1982). 'Time Paths in the Diffusion of Product Innovations,' Economic Journal, 92, pp. 630-653.

Hafstrand, H. (2002). 'Competitive Advantage in the Magazine Publishing Business: a Resourcebased Perspective,' Nordicom Review, 2002 (1), pp. 291-300.

Hujanen, J. (2001). 'From Consuming Printed News to Making Online Journalism? Young Finns' Newspaper Reading at the Millennium,' Nordicom, 2001 (2), pp. 61-69.

Hill, C.W.L. (1988). ‘Differentiation versus Low Cost of Differentiation and Low Cost: a Contingency Framework,' Academy of Management Review, 13 (3), pp. 401-412.

Hitt, M.A., R.D. Ireland and R.E. Hoskisson. (2002). Strategic Management: Competitiveness and Globalization. Cincinnatti, Ohio: South-Western College Publishing.

Hofer, C.W. (1975). 'Towards a Contingency Theory of Business Strategy,' Academy of Management Journal, 18, pp. 784-810. 
Kranenburg, H.L. van, M. Cloodt and J. Hagedoorn. (2001). ‘An Exploratory Study of Recent Trends in the Diversification of Dutch Publishing Companies in the Multimedia and Information Industries,' International Studies of Management and Organization, 31 (1), pp. 64-86.

Kranenburg, H.L. van, F.C. Palm and G.A. Pfann. (2002), 'Exit and Survival in a Concentrating Industry: the Case of Daily Newspapers in the Netherlands,' Review of Industrial Organization, 21, pp. 283-303.

NDP (Dutch Newspapers Publishers’ Association) (1950-97). Annual reports. Amsterdam.

Norton S.W. and W. Norton Jr. (1986). 'Economies of Scale and the New Technology of Daily Newspapers: a Survivor Analysis,' Quarterly Review of Economics and Business, 26, pp. 66-83.

Picard, R.G. (2003). 'Cash Cows or Entrecôte: Publishing Companies and Disruptive Technologies,' Trends in Communication 11(2), pp. 127-136.

Picard, R.G. (2001), 'Strategic Responses to Free Distribution Daily Newspapers,' International Journal of Media Management, 2(3), pp.167-172.

Picard, R.G. and J.H. Brody. (1997). The Newspaper Publishing Industry. Boston: Allyn \& Bacon. 
Picard, R.G., J.P. Winter, M.M. McCombs and S. Lacy (ed.). (1988). Press Concentration and Monopoly: New Perspectives on Newspaper Ownership and Operations. Norwood, N.J.: Ablex Publishing.

Porter, M.E. (1985). Competitive Advantage: Creating and Sustaining Superior Performance. New York: Free Press.

Rosse, J.N. (1967). 'Daily Newspapers, Monopolistic Competition, and Economies of Scale,' American Economic Review, 57, pp. 555-577.

Scherer, F. and D. Ross. (1990). Industrial Market Structure and Economic Performance ( $3^{\text {rd }}$ ed.). Boston: Houghton Mifflin.

Schumpeter, J.A. (1934). The Theory of Economic Development. Cambridge Mass: Harvard University Press.

Schumpeter, J.A. (1942). Capitalism, Socialism and Democracy. New York, N.Y. : Harper and Row.

Sollinge, J.D. (1999). 'Danish Newspapers: Structure and Developments,' Nodicom Review, 1999 (1), pp. 31-76.

Vernon, R. (1966). 'International Investment and International Trade in the Product Life Cycle,' Quarterly Journal of Economics, 80, pp. 190-207. 
Wirtz, B.W. (2001). 'Reconfiguration of Value Chains in Converging Media and Communications Markets,' Long Range Planning, 34, pp. 489-506. 
Table 1: Development of the cost structure of Dutch newspaper publishing firms from 1968 to 1995 in percentage.

\begin{tabular}{|c|c|c|c|c|}
\hline & \multicolumn{4}{|c|}{ Year } \\
\hline & 1968 & 1975 & 1985 & 1995 \\
\hline \multicolumn{5}{|l|}{ Category } \\
\hline Paper & 21,0 & 20,5 & 18,2 & 12,6 \\
\hline Printing & 18,0 & 24,2 & 19,4 & 17,5 \\
\hline Editing & 16,0 & 19,7 & 20,3 & 23,6 \\
\hline Distribution & 18,0 & 9,9 & 13,6 & 15,3 \\
\hline Advertising & 5,0 & 6,1 & 6,2 & 7,0 \\
\hline Subscription & 8,0 & 5,0 & 6,5 & 7,0 \\
\hline Buildings & 14,0 & 14,6 & 15,8 & 17,0 \\
\hline
\end{tabular}

Source: NDP annual reports. 
Table 2: The opportunity for newspaper publishing companies to implement a differentiation strategy successfully to increase demand given the product market environment.

\begin{tabular}{|c|c|c|c|}
\hline & & \multicolumn{2}{|c|}{ Market Structure } \\
\hline & & High Fragmented & Low Fragmented \\
\hline $\begin{array}{c}\text { Stage of Industry } \\
\text { Evolution }\end{array}$ & High Growth Stage & $\begin{array}{l}\text { High opportunity } \\
\text { e.g. web-sites; } \\
\text { Exibitions; CD-roms } \\
\text { and DVDs; direct } \\
\text { marketing activities. }\end{array}$ & $\begin{array}{l}\text { Medium opportunity } \\
\text { e.g. internet provider; } \\
\text { cable operator. }\end{array}$ \\
\hline & Low Growth Stage & $\begin{array}{l}\text { Medium opportunity } \\
\text { e.g. leisure, } \\
\text { professional and } \\
\text { consumer magazines; } \\
\text { Books; Scientific } \\
\text { journals. }\end{array}$ & $\begin{array}{l}\text { Low opportunity } \\
\text { e.g. printed national } \\
\text { and regional } \\
\text { newspapers }\end{array}$ \\
\hline
\end{tabular}

Source: Hill (1988). 